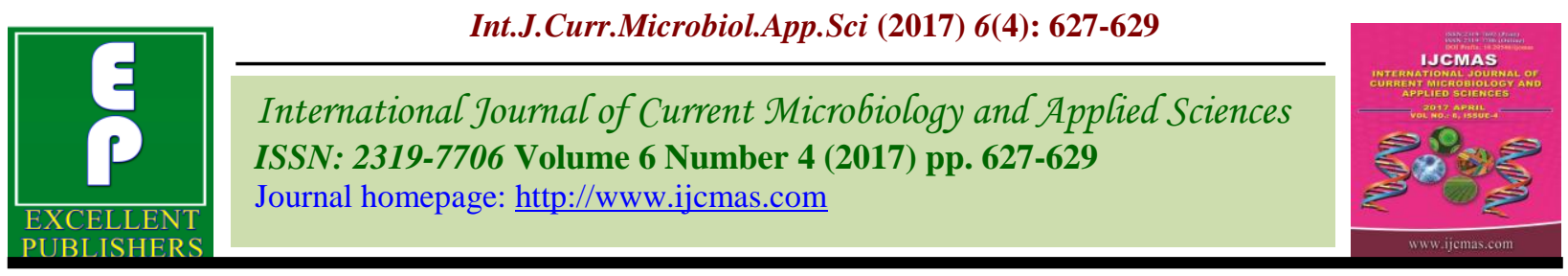

Original Research Article

https://doi.org/10.20546/ijcmas.2017.604.076

\title{
Evaluation of Different Pigeon Pea Hybrids and Varieties for Yield Trait under Central Dry Zone of Karnataka, India
}

\author{
T.N. Dhanalakshmi*, T. Rudramuni, G. Hanumantha Naik, N. Pallavi and D. Chandrappa \\ AICRP on Castor, ZAHRS, Hiriyur, India \\ *Corresponding author
}

\section{A B S T R A C T}

\section{Keywords}

Pigeon pea, Hybrid, Yield.

Article Info

Accepted:

06 March 2017

Available Online:

10 April 2017
Pigeonpea (Cajanus cajan L.) is the second most important pulse crop after Chickpea which constitutes a major protein-rich food supplement for most Indians. Among pulses, pigeonpea observed to be a major source of protein for about $20 \%$ of the world population and with rich source of minerals and vitamins. Pigeonpea dal is playing a vital role as a staple food across the country and playing an important role in National Economic and Nutritional Security. Pigeonpea is widely grown in India with $3.56 \mathrm{~m}$ ha, which contributes $76 \%$ of global area and $2.31 \mathrm{~m}$ tonnes of global production. But present rate of consumption and demand of pulses is increasing annually by $3.3 \%$. In this endeavour, the use of hybrid pigeonpea technology has potential to increase the yield. The present investigation consists of 16 entries sponsored by IIPR, Kanpur was conducted at Zonal Agricultural and Horticultural Research Station, Hiriyur, Chitradurga district, Karnataka during 2015-16 kharif season to study their potentiality mainly with respect to yield and yield attributing traits. The results revealed that there was a significant difference among all the parameters; which indicates that the existence of sufficient variation for effective selection. NTL 30 entry recorded higher yield of $1719 \mathrm{~kg} / \mathrm{ha}$ followed by SKNP 1216 entry of $1555 \mathrm{~kg} / \mathrm{ha}$. The reason behind this higher yield might be because of more number of branches and pods per plant (154) and 100 seed weight (12g).

\section{Introduction}

Pigeonpea (Cajanus cajan) is a legume crop with diploid chromosome number of $2 \mathrm{n}=22$, belongs to family Fabaceae, one of the oldest protein source of human food, in the form of green pods as well as grains since centuries. It is an excellent source of protein, minerals and vitamins and has multiple uses viz., food, feed, fuel, soil enricher, soil binder etc. It also used in fencing, roofing and basket making (van der Maesen, 2006). Although, India produces 2.4 million tons of pigeonpea, the per capita availability of pigeonpea is gradually declining (Saxena, 2005) and one of the main reason for this is widening of demand and supply gap due to mismatch in the growth of human population and production of protein rich pulses. In order to maintain self-sufficiency in pulses production for the ever-increasing population, a proportionate increase in their production is essential. The present investigation was conducted at the Zonal Agricultural and Horticultural Research Station, Hiriyur, Chitradurga district, Karnataka during 201516 kharif season to study their potentiality with respect to yield trait mainly. 


\section{Materials and Methods}

The material for the present study comprised of 16 different entries sponsored by IIPR, Kanpur. The seed material was sown in Randomized Complete Block Design with recommended Agronomic and Plant Protection practices were followed during crop growth period to raise a good crop. The application of recommended dose of fertilizer (25:50:25 NPK $\mathrm{kg} / \mathrm{ha}$ ) applied to the plot. Several yield and yield attributing traits were recorded in pigeon pea crop (Table 1). Each plot consisted 6 rows of $4 \mathrm{~m}$ length with inter and intra row spacing of 60 and $20 \mathrm{~cm}$, respectively. To avoid border effect, one border row plants in all the 4 sides of the plot were excluded from the plot yield and yield $\mathrm{kg} / \mathrm{ha}$, it was calculated considering net plot area $8.6 \mathrm{~m}^{2}$. The Agronomic practices included like Basal application of Recommended Dose of Fertilizers (RDF), two hand weedings and two irrigations were practiced. Data were recorded on days $50 \%$ flowering, Plant height $(\mathrm{cm})$, plant stand at the time of harvesting, Number of primary branches/plant, Number of secondary branches/plant, Number of pods/plant, 100 seed weight $(\mathrm{g})$ and yield $(\mathrm{kg} / \mathrm{ha})$. The statistical analysis was performed using AGROBASE GEN-II software.

\section{Results and Discussion}

The results revealed that there was a significant difference among all the parameters; which indicates that the existence of sufficient variation for effective selection among the entries. Increase in seed yield was due to better synchronization of flowering resulted in higher number of pod set. Among the entries NTL 30 entry recorded higher yield of $1719 \mathrm{~kg} / \mathrm{ha}$ followed by SKNP 1216 entry with an yield of $1555 \mathrm{~kg} / \mathrm{ha}$.

Table.1 Yield and yield attributing traits in pigeonpea hybrids

\begin{tabular}{|l|c|c|c|c|c|c|c|}
\hline \multicolumn{1}{|c|}{ Entries } & $\begin{array}{c}\text { Yield } \\
\text { (kg/ha) }\end{array}$ & $\begin{array}{c}\text { Days to } \\
\mathbf{5 0} \text { \% } \\
\text { flowering }\end{array}$ & $\begin{array}{c}\text { Plant } \\
\text { height } \\
\text { (cm) }\end{array}$ & $\begin{array}{c}\text { Number of } \\
\text { primary } \\
\text { branches/plant }\end{array}$ & $\begin{array}{c}\text { Number of } \\
\text { secondary } \\
\text { branches/plant }\end{array}$ & $\begin{array}{c}\text { Number } \\
\text { of pods } \\
\text { /plant }\end{array}$ & $\begin{array}{c}\text { 100 seed } \\
\text { weight } \text { (g) }\end{array}$ \\
\hline WRGE 90 & 934 & 74.7 & 154.0 & 6.3 & 3.3 & 181.0 & 9.9 \\
\hline AH 12-09 & 340 & 54.3 & 82.0 & 5.3 & 2.3 & 104.0 & 8.5 \\
\hline LRG 160 & 816 & 74.3 & 199.7 & 4.3 & 2.3 & 132.7 & 10.6 \\
\hline SKNP 1216 & 1555 & 66.3 & 195.3 & 3.7 & 3.7 & 118.0 & 10.0 \\
\hline PT 04-378 & 1115 & 75.7 & 193.3 & 3.3 & 3.7 & 165.3 & 11.5 \\
\hline WRGE 92 & 1038 & 79.7 & 215.3 & 3.7 & 2.7 & 147.3 & 10.4 \\
\hline PT 0705-3-1-1 & 1267 & 77.3 & 191.7 & 4.7 & 3.7 & 150.7 & 11.4 \\
\hline BRG 15-4 & 1226 & 55.7 & 222.3 & 5.7 & 2.7 & 102.3 & 12.7 \\
\hline AH 12-11 & 372 & 55.0 & 89.0 & 4.7 & 4.0 & 102.3 & 9.3 \\
\hline RKPV 310-07 & 1142 & 63.0 & 122.3 & 3.3 & 4.7 & 104.7 & 9.4 \\
\hline GRG 177 & 1010 & 82.7 & 147.3 & 3.3 & 2.7 & 104.0 & 11.5 \\
\hline BRG 15-3 & 1062 & 80.0 & 200.0 & 4.7 & 4.7 & 144.7 & 11.4 \\
\hline NTL 30 & 1719 & 75.7 & 195.7 & 3.7 & 2.7 & 153.7 & 11.6 \\
\hline RKPV 449-02 & 826 & 70.3 & 173.0 & 3.3 & 2.7 & 144.0 & 10.5 \\
\hline UPAS 120 (C) & 906 & 61.0 & 112.3 & 3.3 & 3.0 & 101.7 & 8.4 \\
\hline PT 0012 (C) & 1233 & 74.7 & 182.3 & 3.7 & 2.3 & 146.3 & 11.0 \\
\hline SEm \pm & 100.5 & 1.7 & 6.3 & 0.4 & 0.4 & 4.8 & 0.2 \\
\hline CD (0.05P) & 308.0 & 5.0 & 18.3 & 1.1 & 1.3 & 13.9 & 0.7 \\
\hline CV (\%) & 18.0 & 4.3 & 6.6 & 16.2 & 23.8 & 6.3 & 3.8 \\
\hline
\end{tabular}


The reason behind the higher yield might be because of more number of pods per plant (154) and 100 seed weight (12g). Early to medium duration Redgram hybrids with resistance to major diseases and pests are most likely to acceptable by farming community (Saxena, 2015).

\section{Acknowledgement}

The experiment was supported by Indian Institute of Pulses Research (IIPR), Kalyanpur, Kanpur, Uttar Pradesh and Zonal Agricultural and Horticultural Research station, Hiriyur, Karnataka.

\section{References}

Nene, Y.L. and Sheila, V.K. 1990. Pigeonpea: geography and importance. In: Nene YL, Hall SD and Sheila VK (eds) The
Pigeonpea. Wallingford, Oxon: CAB International, pp. 1-14.

Saxena, K.B. and Tikle, A.N. 2015. Believe it or not, hybrid technology is the only way to enhance pigeon pea yields, Int. J. Scientific \& Res. Publications, 5(6): 1-7.

Saxena, K.B. 2005. Opportunities for exploiting hybrid vigour in grain legume for increasing yield and adaptation A success story of pigeonpea. Paper presented in $7^{\text {th }}$ annual symposium of Department of Agriculture held from September $29^{\text {th }}$ to 30th 2005 at Gannruwa, Sri Lanka, Pp. 59-76.

Van der Maesen, L.J.G. 2006. Cajanus cajan (L.) Mill sp. In: Brink M and Belay G (eds) Plant Resources of Africa Cereals and Pulses, Wageningen: Backhuys Publishers.

http://database.prota.org/search.htm

\section{How to cite this article:}

Dhanalakshmi, T.N., T. Rudramuni, G. Hanumantha Naik, N. Pallavi and Chandrappa, D. 2017. Evaluation of Different Pigeon Pea Hybrids and Varieties for Yield Trait under Central Dry Zone of Karnataka. Int.J.Curr.Microbiol.App.Sci. 6(4): 627-629. doi: https://doi.org/10.20546/ijcmas.2017.604.076 